\title{
Public participation power dynamics in strategic development planning in a metropolitan municipality: Eastern Cape Province
}

\begin{tabular}{|c|c|}
\hline \multicolumn{2}{|c|}{$\begin{array}{l}\text { Authors: } \\
\text { Modeni M. Sibanda }{ }^{1} \\
\text { Liezel Lues }^{2}\end{array}$} \\
\hline \multicolumn{2}{|c|}{$\begin{array}{l}\text { Affiliations: } \\
{ }^{1} \text { Department of Public } \\
\text { Administration, Faculty of } \\
\text { Management and Commerce, } \\
\text { University of Fort Hare, } \\
\text { Bisho, South Africa }\end{array}$} \\
\hline \multicolumn{2}{|c|}{$\begin{array}{l}{ }^{2} \text { Department of Public } \\
\text { Administration and } \\
\text { Management, Faculty of } \\
\text { Economic and Management } \\
\text { Sciences, University of the } \\
\text { Free State, Bloemfontein, } \\
\text { South Africa }\end{array}$} \\
\hline \multicolumn{2}{|c|}{$\begin{array}{l}\text { Corresponding author: } \\
\text { Modeni Sibanda, } \\
\text { mmsibanda@ufh.ac.za }\end{array}$} \\
\hline \multicolumn{2}{|c|}{$\begin{array}{l}\text { Dates: } \\
\text { Received: } 30 \text { Sept. } 2021 \\
\text { Accepted: } 16 \text { Nov. } 2021 \\
\text { Published: } 17 \text { Dec. } 2021\end{array}$} \\
\hline \multicolumn{2}{|c|}{$\begin{array}{l}\text { How to cite this article: } \\
\text { Sibanda, M.M. \& Lues, L., } \\
\text { 2021, 'Public participation } \\
\text { power dynamics in strategic } \\
\text { development planning in a } \\
\text { metropolitan municipality: } \\
\text { Eastern Cape Province', } \\
\text { Journal of Local Government } \\
\text { Research and Innovation 2(0), } \\
\text { a44. https://doi.org/10.4102/ } \\
\text { jolgri.v2i0.44 }\end{array}$} \\
\hline \multicolumn{2}{|c|}{$\begin{array}{l}\text { Copyright: } \\
\text { (C) 2021. The Authors. } \\
\text { Licensee: AOSIS. This work } \\
\text { is licensed under the Creati } \\
\text { Commons Attribution } \\
\text { License. }\end{array}$} \\
\hline Read online: & \\
\hline 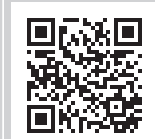 & $\begin{array}{l}\text { Scan this } Q R \\
\text { code with your } \\
\text { smart phone or } \\
\text { mobile device } \\
\text { to read online. }\end{array}$ \\
\hline
\end{tabular}

Background: Public participation in municipal strategic development planning processes does not occur in a vacuum; it is juxtaposed within contextual community realities of power, politics, institutional, systemic practices, cultures and inequities in resource capacity, amongst other relational social practices.

Aim: The aim of this study was to explore the nature of power dynamics in participatory governance platforms and spaces during municipal strategic development planning processes and the extent to which they impact developmental outcomes in a metropolitan municipality.

Setting: A metropolitan municipality in the Eastern Cape Province, South Africa.

Methods: An interpretive, constructivist, cross-sectional exploratory case study collected indepth qualitative data from purposefully sampled participants $(n=34)$ using focus-group discussions. Qualitative data were processed using NVivo 8 computer software and analysed using a thematic analysis approach.

Results: The results indicated mixed views on participants' satisfaction with public participation in municipal strategic development planning processes. Participants reported inadequate knowledge, capacity and capability; resource limits; political exclusion and language barriers, which muted community voice and disempowered, marginalised and excluded some residents from meaningfully participating and articulating community voice, priorities and needs.

Conclusion: Public participation in municipal strategic development planning in the metropolitan municipality is at best tokenistic, constituting mere 'window dressing,' co-option and 'pretence' of inclusion of communities/residents in public participation platforms and spaces. Whilst on the surface, public participation appears inclusive of a range of stakeholders, at best powerful andr elite interests shape strategic development planning outcomes. A local governance framework for enhancing community voice in public participation platforms and spaces is recommended.

Keywords: public participation; power dynamics; strategic development planning; structuration theory; local governance; metropolitan municipality.

\section{Introduction}

In Agenda 2030 on Sustainable Development, 'leaving no one behind' emphasises inclusivity and citizen empowerment in development initiatives. However, in many cases, communities are afforded little opportunity to formulate development policy programmes. In such cases, public participation becomes merely a 'form of decoration and tokenism, where communities or residents are either used as adornments for pre-set agendas or are only involved through pseudo-participation' (Masuku \& Macheka 2020:8). Local governance remains unaccountable without a community voice demanding accountability (Masuku \& Macheka 2020:10; Walker 2018:181-182). Meaningful public participation is touted as a critical ingredient of democratisation, local governance and sustainable development (Mankuebe \& Manicom 2020:370). Inclusive governance is reiterated in Sustainable Development Goal 16, which promotes inclusive societies and sustainable development. Inclusivity is predicated on the right of all citizens to participate meaningfully in the governance processes and to influence policy decisions that affect them (Oni et al. 2020:2-5). Both public participation and inclusive governance originate from the theory of deliberative democracy. Deliberative democratic 
theory has close affinities with public administration values of inclusiveness, responsiveness, answerability and transparency of governance institutions. Accordingly, deliberative democracy directly affects the legitimacy of policy choices and the underlying governance systems, structures and institutions (Oni et al. 2020:5).

Nevertheless, public participation, democratic citizenship and public accountability have an uneasy coexistence in local governance. The extent and substance of public participation have been and continue to be a matter of contention for governance and democratic theory (Buccus 2021:e2720; Zakhour 2020:350). Ironically, whilst public participation is consistent with democratic citizenship, much of what governments do is complex and requires technical competency and expertise to make policy decisions. Where technical knowledge is needed, too few voices are heard (Van Holm 2019:136). Resourcing is also a source of relational power. Resources are deployed by social actors and stakeholders to reproduce or change power structures in public participation platforms and spaces (Coelho, Pozzebon \& Cunha 2021:2). Paradoxically, the administration often positions and opens its work to participatory feedback for legitimacy within the confines of often conflicting public values, responsibilities and accountability expectations (Eckerd \& Heidelberg 2020:133). Democracy, however, continues to be affected by the Habermasian public space (Habermas 1996) - a 'participatory society', 'citizen-centric' or 'people-centric' model of democracy - where the public is a constituent power (Parvin 2021:268). This exposes the enduring classic tenets of public administration, realising both the promises of the administrative state (Waldo 1981) and the political values of democracy to a participatory philosophical paradox. As Parvin (2021:278) aptly puts it, 'the strengthening of democracy requires the weakening of democracy'. This implies that the empowerment of citizens necessitates their disempowerment (Parvin 2021:278).

Wilson (1887:215) had similarly affirmed that public opinion must reign supreme in policy formulation, but opined that it could also be a 'clumsy nuisance, a rustic handling of delicate machinery'. It is argued that whilst democracy is an essential administrative value, it is just one amongst several other values. Wilson thus declared that it is the task of 'administrative study [to] find the best means for giving public criticism' control over the matters of formative policy 'and for shutting it out from all other interference' (Wilson 1887:215). Frederickson (1980:97) also observed that 'effective public administration has come to be defined in the context of an active and participatory citizenry'. Situated within an instrumentalist perspective, Eckerd and Heidelberg (2020:135) postulated that public participation is worthy to the extent that it improves decision-making. Public participation furthers the ex ante goals of the agency. Thus, in that regard, it can improve social justice outcomes and generate citizen-government trust (Eckerd \& Heidelberg 2020:135).
By so doing, public participation may increase policy legitimacy, government efficiency and the promotion of social justice. It may advance governance effectiveness by promoting community voice in policy decision-making processes (Van Holm 2019:136). However, whilst public participation structures may comply with legislative prescripts regarding public inclusion, deliberation is often tokenistic and unevenly distributed. Power asymmetries (Fung 2003) often mediate public participation amongst the wealthy, older, more educated, well networked, better resourced or beneficiaries of the status quo (Eckerd \& Heidelberg 2020:135). Income inequality, socioeconomic status and education are significant predictors of the rate of participation and the roles accorded to participants because of their relationship with social capital and resource availability (Van Holm 2019:136). Pateman's (1975) notion of 'extended citizenship' calls for citizen control and power in the advent of entrenched structural inequalities.

Similarly, Landemore (2017:7) called for a decoupling of deliberative 'citizen-centric', people-centric democracy from elite-centric' or 'government-centric' representative democracy. However, whilst participatory democracy calls for structural inequalities in liberal societies to be rectified, it often does not possess the ability to do so (Parvin 2021:265). In Pateman's theorisation (2012:15), participatory democracy must exist where a participatory society exists first. Hence, citizens should be empowered stakeholders in the co-production and cocreation of public value (Eckerd \& Heidelberg 2020:136).

Public participation is connected to notions of power, agency, empowerment and inclusivity of the marginalised and less powerful in decision-making processes (Arnstein 1969). To development theorists, participatory democracy implies the need to empower especially the less powerful, disadvantaged and often marginalised community segments in decision-making processes on the design and implementation of policies impacting their well-being (Gaventa \& Valderrama 1999; Khan \& Ara 2006). Arnstein (1969:216) advances that 'participation without the redistribution of power is an empty and frustrating process for the powerless'. A symbiotic relationship exists between power and 'community voice'. The public sphere is a plausible space for enabling voice, consciousness, agency and social justice (Masuku \& Macheka 2020:7).

Closely associated with the notion of public participation is empowerment. Rolfe's (2016:99) community empowerment proposition encapsulates community voice and localist discourses. In reality, however, not all groups and their wellbeing are always represented (Sibanda \& Lues 2019:79) or empowered, nor do they possess intrinsic agency (power within), instrumental agency (power to) and collective agency (power with) to navigate the intricate power dynamics intrinsic in participation platforms and spaces (Yount et al. 2019:1). Often public participation platforms and spaces neglect and ignore the capacity of such spaces to manage the 
pervasive, complex power dynamics amongst stakeholders in municipal strategic development planning processes.

The researchers explored the nature of public participation power dynamics in participatory governance platforms and spaces during municipal strategic development planning processes and the extent to which they impact developmental outcomes in a metropolitan municipality. It is argued that public participation is influenced by actors' interests and actions, with the most influential actors usually controlling the participation process. Power can be used to include and exclude actors in participation platforms and spaces. Power dynamics create, produce, reproduce and transform public participation platforms and spaces within structures of social systems bound, reproduced and mobilised by agents during public deliberation (Coelho et al. 2021:7). Power, therefore, influences decisions and includes and excludes actors. A lack of resources, voice or legitimacy excludes less powerful actors (Coelho et al. 2021:7).

Deconstructing societal and power structures that militate against community voice requires critical consciousness in those living on the margins, who experience conditions of exclusion, unjust power inequalities and marginalisation in public participation platforms and spaces. However, invisible power structures and the everydayness of power dynamics reproduce and perpetuate inequality and exclusion (Kezar 2011:475; Machin \& Ruser 2021:215). Unmasking such structures, systems and practices makes them easier to navigate. By viewing public participation as a redistribution of power and an agency facilitating the process, the researchers sought to unravel how manifestations of public participation, power dynamics and community agency shape, in complex ways, why and how public participation may or may not be a space for giving voice to community priorities and needs in municipal strategic development planning processes.

\section{Conceptualising and theorising public participation power dynamics}

Public participation is community engagement at the grassroots level (Christensen \& McQuestin 2019:456; Koens \& Gunawardana 2021:464; Masuku \& Macheka 2020:8; Nikku \& Rafique 2019:880-888). Its values embrace, but are not limited to, inclusiveness, openness, access, consultation, shared decisions and transparency (Oni et al. 2020:5). Murambo (2008:124-127) stated that citizens' voices and participation are at the centre of democratic government. For Bernhardt (2015:136), public participation is the direct or indirect involvement of community members in policymaking and decision-making processes. Munyinda and Habasonda (2013:13) contended that it is 'an instrument of deliberative democratic systems'. Auriacombe (2015:60) viewed it as the process through which the government seeks input from communities on what they want their government to do, as well as how, when and where they want it to do. In terms of Section 19 of the Constitution of the Republic of South Africa,
1996 (RSA 1996), every citizen is free to make political choices and participate in political processes. Public participation is, as a result, a process of engagement in governance, in which 'people participate together for deliberation and collective action within an array of interests, institutions and networks, developing civic identity and involving people in governance processes' (Cooper 2005:534). It is a process through which stakeholders influence and share control over development initiatives and the decisions and resources that affect them (Nikku \& Rafique 2019:880-882). Nikku and Rafique's (2019:880-888) view affords communities' social and political action to expand choices, opportunities, equity and social justice in local governance.

Public participation is a crucial tenet of democracy (Lues 2014:791). Similarly, the governance paradigm emphasises the need for public participation in the design of public policy and decision-making processes (Przeybilovicz et al. 2020:5). Pandeya (2015:68) viewed it as the processes in which citizens take part in governance processes. For Christensen and McQuestin (2019:456), it is an a priori theoretical concept in local democracy discourse and is at the core of participatory democratic governance (Mankuebe \& Manicom 2020:370). It is a socially transformative action that seeks to redistribute power to the marginalised (Cornwall 2016).

Consequently, it denotes how individuals and groups contest and redistribute unequal power relations that limit agency in their daily lives (Koens \& Gunawardana 2021:464). As a concept, public participation draws on the dialectical relationship amongst authority, influence and power by covering 'taking part' and 'being part' of the decision-making process (Gyan 2021:2). The above-mentioned closely resonates with Makiva, Bob and Davids (2021), who explained that public participation is:

The $[p]$ rocess whereby stakeholders exercise influence over public policy decisions and share control over resources and institutions that affect their lives, thereby providing a check on the power of their government. (p. 173)

Dismantling and transforming unequal power relations calls for the exercising of agency. Through democratic agentic acts, decision-making power shifts to individuals, communities and citizens (Coy et al. 2021:101871; Koens \& Gunawardana 2021:467). It entails the process of identifying and taking action to challenge and reform unequal power relations (Koens \& Gunawardana 2021:468). Thus, at the heart of public participation is the notion of agency. For Sen (1999:19), agency denotes the freedom to act and make value changes within an actor's everyday lived experiences. Through the exercise of agency, inequalities, exclusions, oppressive structures, embedded structural societal cultures, and norms are dismantled, often in a recursive process (Gammage, Kabeer \& Van der Meulen Rodgers 2016:1). Dismantling structures to expand the freedom to exercise agency is a process of empowerment. Agency is often driven by empowerment. For Ibrahim and Alkire (2007:384), expanding one's ability to make choices is indicative of empowerment 
as the 'expansion of agency' (Ibrahim \& Alkire 2007:384). Agency intersects with critical consciousness and social advocacy. Critical consciousness, social advocacy and human agency drive transformative social change and community development through active 'community voice' in participatory spaces.

\section{Structuration theory and power dynamics}

The postmodernist turn in social theory birthed Giddens' (1984) structuration theory. Giddens (1984) suggested that individual human agency and social structures are mutually dependent - a concept he calls 'duality' (Sommerfeldt 2012:273). In his schema, Giddens (1984) proposed that every action involves human agency and the instantiation of structures (rules and resources), thus forming a duality. Human agency denotes the capacity to make a difference and to have a transformative capacity (Giddens 1984:14). Human agency is often constrained or enabled by structures, social systems and other reproduced social practices. Giddens' (1984) theory postulates that actions produce and reproduce both constraining and enabling social structures, which are outcomes of social production and reproduction (Giddens 1976). In structuration theory, the structure is held as 'the rules and resources recursively implicated in social reproduction' (Giddens 1984:xxxi). Social change is effected through the exercise of agency. Structure influences agents by giving them power, constraints and vested interests. Agency affords one the transformative capability to do things and effect change, where power is embedded.

In contrast, structures are assemblages of rules and power resources (Giddens 1984:24). In structuration theory, resourcing is a fundamental construct. There is also a dialectical relationship between resourcing and power. Giddens' (1984:50) conception of power views it as having two faces: it constrains and empowers the agent through human action.

Giddens' (1984:15) power resource thesis argues that power is embedded in a pre-given social order, and agents' capacity for transformative change is bound to power resource mobilisation, inherent in structures and constituents of institutions. Social systems are therefore held together through an accumulation of power resources. In Giddens' (1984:164) schema, social systems are ensembles of reproduced practices across time and space. The more power resources are stored, the more powerful a social system gets. Giddens' (1984:16) notion of the 'dialectic of control' in social systems posits that a social system not only marginalises and disempowers, it also empowers agents. Control is the capability that some actors have of influencing the circumstances of action of others (Giddens 1984:283). In structuration theory, accounts of power are interwoven with solid notions of agency, and social change is a function of agents' consciousness (Hildebrand \& Martell 2012:190).
Accordingly, agents are not always at the mercy of their social position. Agents' consciousness provides the wherewithal for reflection upon social situations, behaviour and the self. Consciousness allows one to coherently account for one's activities and the reasons for them (Giddens 1984:45). In this sense, actors are viewed as powerful and knowledgeable beings, with reflexive capabilities for monitoring the 'ongoing flow of social life' (Giddens 1984:5). In structuration theory, actors negotiate and re-negotiate their positions within society through agency. Bakewell (2010:1694) expounded that agency is the capacity of social actors to 'reflect on their position, devise strategies and take action to achieve their desires'. In Giddens' (1984:17-21) postulation, systems are reconstituted by structures, with structures generating behaviour patterns in the enactment, production and reproduction of social life. Such behaviour patterns (termed schemas or rules) are the means through which agents act in society (McGarry 2016:2073). The multiplicity of structures and schemas is a crucial characteristic of structure, which enables agents, as strategic actors, to act in multiple systems (Sewell 2005:141-142). Conflicting structures and schemas often reconstitute systems in which agents' lives are embedded. Agents' power or capacity for action is enhanced by acting through schemas to gain access to resources (McGarry 2016:2074). However, in agents' consciousness, structures are only memory traces amenable to transformation through action.

As such, structuration theory acknowledges the role of power dynamics in mediating power asymmetries inherent in structures of society. Hence, in structuration theory, power enables or constrains interaction and exists in social contexts, 'manifesting itself in the dialectical interplay between agency and structure' (Giddens 1984:226). Within this dialectic of control, power's ability to constrain or enhance actors' agency is contingent upon the ability of public participation stakeholders to act, subject to structures within the contexts. Stakeholders may, for example, attempt to 'manage resources in such ways, as to exert control over more powerful established power relationships' (Giddens 1984:374). Access to resources provides stakeholders with the power and wherewithal to transform structures. Agency is accordingly enhanced or constrained by structure. In Giddens' (1984:176) own words, 'one person's constraint is another's enabling'. As argued by Durham (2005:44), structuration theory provides a potent analytical schema for holistically comprehending power and generating consciousness and as a structuring agent - 'a process of structuration', dictated by Giddens' dialectic of control. Structuration theory, therefore, allows us to reconceptualise the public-institutional interaction (Cozier \& Witmer 2001:619).

\section{Governmentality and power dynamics}

Governmentality can be treated as a synonym of liberal government and governmental management (Esmark 2018:245). As a term, Barthes first used it in 1957 to link 
government processes with efficiency (Barthes [1957]1972; McKinlay, Carter \& Pezet 2012:6). As a process, it designates how the conduct of individuals or groups might be directed (Bulley \& Sokhi-Bulley 2014:453). Within this logic, to govern is to control the possible field of action of others (Foucault 2002:341). Gordon (1991:2) succinctly defines governmentality '... as "the conduct of conduct" - that is, a form of activity or practice that aims to shape, guide or affect the conduct of some person or persons'. Gordon (1991:3) further explained that, as methodology, governmentality refers to 'a way of thinking about the practice of governance: who can govern, what governing is and what or who is governed'. It is a 'govern/mentality' (Barron 2005:984). Within the context of public participation, responsibility is at the heart of governmentality. An excellent democratic society is a responsible society, built on the virtues of civility, with the public taking responsibility (Bulley \& Sokhi-Bulley 2014:455). The hegemonic nature of public participation power dynamics is partly because of their structural articulation by governments and other influential public and social institutions. Public participation power dynamics can thus be conceptualised in terms of Foucault's notion of 'governmentality'. Governmentality is an organising framework of practices and technologies in the exercise of power to have effects on the conduct (i.e. action on the actions of the others) by the powerful (Foucault 2007:109). Access to resources shapes power dynamics, either negatively or positively, with profound implications for participatory governance, democratic legitimacy and the governmentcitizen nexus (Coelho et al. 2021:20).

Thus, governmentality embraces both governments of the self and individuals by each other and by the state 'governmentalities of self and others' (Foucault 2019:288). This conception captures the totality of numerous power relations in society (Kim 2021:186). This locates public participation power dynamics within the context of what Foucault calls hegemonic exercise of power, which aims to discipline, control and marginalise (Finlay \& Hopkins 2019:5). This form of power is essentially the practice of governing, controlling and subjugating the populace. It is the consolidation and exercise of government power in everyday culture and everyday practices. It is thus imperative to theorise power dynamics as the exercise of power in everyday culture and everyday practices: a power that 'travels between state, society and citizens' (Kaya 2014:24). Resourcing permits the production of new resources, which when deployed, can change structures of power (Coelho et al. 2021:22).

Space is central to the exercising of power (Gaventa 2006:25). The public sphere is an arena of public discourse and communicative rationality (Finlay \& Hopkins 2019:5). Marginalised spaces are not spaces entirely outside the public space, but rather on the periphery of the public sphere, where community voices in public participation spaces are undervalued and silenced (Finlay \& Hopkins 2019:5). Governance networks emphasise partnerships, co-operation and collaboration. Four theories define governance networks: interdependence theory, governability theory, integration theory and governmentality theory (Sørensen \& Torfing 2005:208). Integration theory views governance networks as institutionalised fields of interaction between relevant actors, which are integrated into a community defined by shared norms and perceptions (Sørensen \& Torfing 2005:209). Governance theory implicitly advocates that governance networks are an attempt of an increasingly reflexive and facilitating state to mobilise and shape the free actions of selfgoverning actors (Sørensen \& Torfing 2005:209). Gaventa (2006:25-29) distinguished between 'three forms of power: visible, hidden and invisible forms'.

Localism is a well-established policy discourse in most Western liberal democracies (Wargent 2021:571). Proponents draw discursive links between localism and citizen empowerment, community control, responsive governance and deepened democracy (Wargent 2021:571). A unifying assumption within this discourse is that power can simply be 'put in the hands' of local people. This notion is advanced by theorists adopting a governmentality perspective predicated on Foucault's (1990:93) synaptic conception of power that 'comes from everywhere', operating through social actors and their relations. Governmentality explains how power operates in societal structures by creating discourses, subjects, potential resources and institutional systems and structures (Foucault 1991). Localism is thus governmental rationality. 'Proper' distribution of power is made explicit throughout the localist discourse.

As a concept, governmentality helps one to comprehend power's varied and intersecting forms, opening out the power dynamics behind how power is propagated and experienced in organisational, governmental and societal institutions, systems and structures (Finlay \& Hopkins 2019:5). As postulated by Foucault (2002:361), 'space is fundamental in any form of communal life; space is also fundamental in any exercise of power'. However, Foucault (1990:93) also stated that 'power is everywhere'; it is not the exclusive property of hegemonic subjects. There is also power from below, exercised by the less powerful, which Foucault terms 'resistance'. This closely resonates with Hooks' (1989) view of marginality as a space of resistance and deprivation. Foucault (1982:783) similarly argued that resistance is a struggle against power. Hence, public participation power dynamics can become a struggle to gain control, undermine and resist hegemonic powers seeking to construct, reconstruct and control systems and structures of public deliberation spaces. Paradoxically then, for some, the public sphere is a space of resistance, whilst for others, it is a potential space of insecurity and vulnerability, which they seek to avoid (Finlay \& Hopkins 2019:5). This highlights that public participation power dynamics may push other local governance stakeholders, including residential communities, into marginalised spaces. When they intersect with institutional, systemic, political and societal structures, they can marginalise agency and diminish confidence and trust in local governance decision-making processes. 


\section{Methodology}

The researchers adopted postmodernist, interpretive epistemological, and constructivist ontological positions (Fouche, Strydom \& Roestenburg 2021:7). Interpretivism assumes that social reality is interpreted subjectively, that the 'knower' and 'known' are interdependent, and that reality is multilayered and complex and has multiple interpretations (Fouche et al. 2021:7). Constructivists view reality as a product of a series of constructive processes and hold that only a narrative truth exists (Maree et al. 2016:4-5). Constructivism is based on the ontological assumption that the 'public' actively and agentially seek out, select and construct their views, worlds and meanings. Such processes are rooted in sociocultural contexts, interaction and deliberation (Cohen, Manion \& Morrison 2018:19-23), committing to social justice and empowerment (Fouche et al. 2021:9). Thus, for constructivists, empowerment as a process includes increases in intrinsic agency (power within), instrumental agency (power to) and collective agency (power with) (Yount et al. 2019:1).

A constructivist, interpretivist worldview allowed the researchers to explore public participation power dynamics as inherently emotional, historical, cultural and contextual, as situated stories/narratives of communities and local governance stakeholders embedded within webs of beliefs and social structures (Källström et al. 2020:4). The assumption was that reality consisted of people's subjective experiences of the external world. The researchers, therefore, embraced an intersubjective and empathetic epistemology, which used qualitative and interactional approaches (Maree et al. 2016:4). Participants' views were taken as 'fact', based on the assumption that participants constantly interpret and reinterpret their world - social situations, other people's actions, their actions and humanly created objects and social spaces (Blaikie 2007:124). Concurring with Babbie (2016:293-294), the researchers were also of the view that immersing themselves in participants' viewpoints would allow them to obtain in-depth data on feelings, meanings, perceptions and beliefs (Blaikie 2007:131; Easterby-Smith, Thorpe \& Jackson 2008:116).

The constructivist, interpretivist worldview aligns with a decentred theory of governance by taking a humanist and historicist perspective and a constructivist and historical social ontology (Källström et al. 2020:4). Such a decentred theory emphasises the social construction of practices through the ability of individuals to create and act on meanings (Bevir 2013:56-57). The researchers assumed that, in the case study, practices and local governance narratives would make it possible to unpack the contested social and structural constructions situated in power relations and asymmetries (Bevir 2013:65). It was assumed that inequalities and exclusion were situated in and mediated by public participation power asymmetries and social structures and were a consequence of how individuals and society perceived social relations (Cohen et al. 2018:24).
Therefore, meaning-making power dynamics, overt and covert power issues and structuration practices were typical of interpretative, constructivist studies and the qualitative research approach (Ospina, Esteve \& Lee 2018). The researchers embraced post-foundationalism, based on meaning holism. Meaning holism is premised on the assumption that propositions, meanings and beliefs can only be fully understood in the context of structural, systemic, societal and institutional public participation power dynamics. From this paradigmatic standpoint, administrative behaviour and public administration were less about correlations or associations amongst variables and more about experiences, stories/narratives, beliefs, actions, practices, meanings and how they are contingent on context and subjectivities (Bevir 2011:190).

The researchers thus adopted a qualitative approach, and data were collected through focus-group discussions (Maree et al. 2016:95). The exploratory case study design enabled the researchers to understand public participation power dynamics in municipal strategic development planning in the metropolitan municipality case study. A case study had the advantage of yielding in-depth explanatory insights (Babbie 2016:302). The target population comprised ward councillors, ward committee members, integrated development plan (IDP) representative forum members and community stakeholders.

Four focus-group discussions were conducted (Maree et al. 2016:95-97). One focus-group discussion was conducted with each of the following sample groups: 8 ward councillors, 9 ward committee members, 7 IDP representative forum members and 10 community stakeholders. Purposive sampling enabled the researchers to achieve the typicality of settings in the selected metropolitan municipality (Babbie 2016:187; Bless, Higson-Smith \& Sithole 2013:172; Maree et al. 2016:198). The selection was further based on the need to adequately capture the heterogeneity in the target population (Warren, Gerber \& Robinson 2013:128). Another goal was to select information-rich cases. Out of the original sample of 40 participants $(n=40)$, only 34 (constituting $85 \%$ ) of the original sample attended the focus-group discussions. For Bless et al. (2013:200-201), focus groups are a quick and inexpensive way of collecting data from participants (see also Maree et al. 2016:97). Focus-group discussions allowed participants to build on each other's ideas and comments. The researchers thus found focus-group discussions suitable for collecting indepth qualitative data (Bless et al. 2013:200-201).

Hence, Polkinghorne (2005) explained that qualitative researchers most often use a small number of participants in their studies. In support of the given explanation, Curry, Nembhard and Bradley (2009) argued that the sample size varies depending on the breadth and complexity of the inquiry. Thus, the adequacy of the sample size is determined by the principle of theoretical saturation. Schwandt (2001) posited that theoretical saturation is reached when additional analysis no longer contributes to anything new about the 
concept or experience under study. From the given discussion, it is apparent that there is no agreed-upon sample size in qualitative research. Hence, for this article, an adequate sample size was subjectively decided to be 20 . Data were collected from this sample using the data collection methods discussed in the following paragraphs.

The validity, the extent to which a study measures what it claims to measure (Maree et al. 2016:122), was considered. Internal validity, the extent to which extraneous variables that might interfere with the results, was controlled (see Maree 2007:216-218). Threats to internal validity such as history, pretesting, instrumentation, subject attrition, maturation and diffusion were mostly guarded against. External validity, the extent to which findings can be generalised (Babbie 2016:148-152), was also considered. This implies that if several focus groups expressed similar attitudes or experiences, it could be argued that the groups represent the opinions and experiences of a larger population, that is, the sample group.

Data were analysed using a thematic analysis approach. Rigorous, systematic coding and categorisation of significant themes were conducted on the focus-group discussions' transcripts and notes (see Creswell 2007:244). Qualitative data were processed using NVivo 8 computer software. Data analysis involved assigning descriptive labels (open codes) to text passages, clustering similar codes and assigning inferential labels or pattern codes (Maree et al. 2016:116). The constant comparison was used to determine whether the data segments were in the most appropriate categories and themes. The themes that emerged from the data were then interpreted and discussed. In the qualitative data, trustworthiness was established (Creswell \& Creswell 2018:166) by adopting the credibility, transferability, dependability and confirmability criteria advocated by Nowell et al. (2017:3-4).

\section{Results and discussion}

This section presents and discusses the findings structured around the themes that emerged from focus-group discussions. Verbatim quotes are selectively used to give voice to the participants and to illustrate participants' perceptions and views.

\section{Satisfaction with participation in municipality's strategic development planning}

Satisfaction is a psychological feeling and experience generated and affected by the differences between the public's perceptions and their expectations of service delivery in a municipality ( $\mathrm{Xu} \& \mathrm{Zhu}$ 2020:4). It is 'an evaluative attitude or behaviour towards some experience or object' (James 2009:108). Perceived quality and perceived value were used to reflect the impact process of public participation on satisfaction (Xu \& Zhu 2020:4). Previous studies have shown that public participation positively affects citizens (Wu \& Jung 2016). Public value is intrinsically linked to a collective notion such as 'the general interest', captured by Moore (2013:58) as 'the collective arbiter of public value'. The discourse on public value draws on notions of democracy and public interest.

As a result, 'public satisfaction' becomes a possible public value. Consequently, community expectations and satisfaction vary concerning contextual public preferences, perceived quality and value (Mangai 2016:89). The focus-group discussions showed mixed views on participants' satisfaction with public participation in municipal strategic development planning in the metropolitan municipality under study.

Results from focus-group discussions showed the following sentiments. One participant pointed out:

'In my area, everyone participates equally despite political backgrounds. In the IDP meetings, the community is free to raise their needs and identify the projects they want.' (IDP representative forum member)

A ward councillor in the metropolitan municipality had this to say regarding satisfaction with public participation platforms and spaces:

'In many instances, identified projects in my ward have been accepted by the municipality. Yes, of course I am satisfied. ... I start the process from the planning stages up to the final stage [adoption stage].' (Ward councillor)

A community stakeholder expressed dissatisfaction with the efficacy of public participation platforms and spaces in influencing strategic planning outcomes in the metropolitan municipality. The participant commented:

'I get invited and attend. ... I get involved in any process preceding the integrated development planning meetings. ... I do participate, but at times priorities as been [sic] given by the community are not adhered to, they do not get included.' (Community stakeholder)

Participants also expressed mixed feelings about their satisfaction with the participation of stakeholders, such as the IDP representative forum. Another participant revealed:

'They [IDP representative forum] cover the needs of the community where they come from [sectoral integration]. ... Relevant people are brought in to explain their fields.... It is the IDP forum which shapes the direction of the IDP.' (Community stakeholder)

Another community stakeholder commented:

'I don't know if [the IDP representative forum] it exists. ... I don't know because I never heard about it before, but as ward committee, I want more information to have for the community.' (Community stakeholder)

A member of the IDP representative forum emphasised the need for sectoral integration, emphasising that: 
'Our sector plans should be an integral part of our municipality ... in our IDP ... because it takes into account different views and that all stakeholders participate freely without fear.' (IDP representative forum member)

These findings reveal a mixture of exposure, vulnerability and threat to public participation in the metropolitan municipality's municipal strategic development planning review processes. Corporatism requires that public participation be subordinated to local governance structures. However, as Tew (2005:77) postulated about public participation spaces, dominant perspectives may be policed by disallowing the possibility of an alternative. Rutgers (2015:39) viewed shared values as specific values that concern 'the good society' or 'the general interest'. The possibility of public participation in municipal strategic development planning review processes creating public value resonated with focus-group participants, some of whom had this to say:

'If the representatives can be active and trustworthy, the outcomes would be positive because they are presenting the community needs and influencing the IDP outcomes. I strongly believe that these forums will make the people's voice to be heard.' (Ward councillor)

'Different stakeholders bring projects that can change people's lives.... IDP representative forum is comprised of all stakeholders. ... IDP representative forum has all departmental representatives, business community, NGOs and elite groups [interest groups].... My take is: surely they are there to benefit themselves. ... They support each other.' (Ward committee member)'

'Although we [IDP representative forum] have less influence. ... They [community needs] can be determined by the priority order. Strong interest groups have more influence as to the final product. ... It would be helpful if the municipal councils can work according to IDP outcomes as suggested by communities. ... It's all about community needs, isn't it?' (IDP representative forum)

Dissatisfaction with public participation in municipal strategic development planning in the metropolitan municipality was discerned from some participants who felt that:

'Not enough is being done to educate the community about the importance of the IDP and public participation, therefore most do not attend or a few educated ones attend. ... Issues raised by the community remain the same throughout the system. The ruling party does not do well, they do not listen to public views, and they influence the people with their own decisions using their members.' (Ward committee member [opposition])

'The community needs to be given more knowledge, so they could be able [to] understand what is expected of them. Integrated development plan (IDP) does not satisfy community needs, because most residents don't participate as they don't really understand the importance of taking part in the process. They don't hear most of our views.... Public participation doesn't make us aware of the IDP. Our ward area is vast so people are not heard.' (Community stakeholder)

A community member pointed out:

'Municipality is not implementing the needs of the people, because some things people want, the municipality does not do it at all. ... That is why people get angry and burn the streets all the time. Some things are done quickly to the other communities, to some they do not do totally. Some of them, they take time, such as houses, electricity. Because there is nothing happening it is only empty promises.' (Community stakeholder)

Another participant expressed dissatisfaction with the outcome of municipal strategic planning, saying with exasperation:

'Integrated development plan document is a cut and paste and is the same every year. No implementation and evaluations of projects.' (IDP representative forum member)

These findings indicate that the contextual background is related to the expectations and satisfaction of the inhabitants of a neighbourhood or community. In their study, Wang, Jun and Wang (2021:60) established that the public's performance expectation plays a moderating role, mitigating the influence on public satisfaction. For Bozeman (2007:12), the public interest is the outcome best serving the long-run survival and well-being of a social collective as a public. Public value is predicated on the notion of the public sphere, public interest and political instruments that create public value. Participants' experience with public participation spaces in municipal strategic development planning suggested a mixed bag of satisfaction, frustrations and dissatisfaction.

\section{Capability as power in public participation platforms and spaces}

The issue of limited capacity to fully understand the strategic nature of municipal strategic development planning amongst community members was a recurring theme. Participants believed that a lack of capacity and/or capability reproduced the marginalisation of residents from meaningfully participating and articulating community needs and policy preferences. A recurring theme was that the IDP was fully not understood by many community stakeholders, including those who represent them, the ward committees. Qualitative data from focus-group discussions indicated that residents of the metropolitan municipality lacked functionings and capabilities (Sen 1999) in strategic development planning processes. One participant reflected as follows on the strategic development planning outreach programmes in the metropolitan municipality:

'Most questions from residents during IDP outreach programmes are based on houses and electricity and also jobs for the people. ... There are lots of disagreements on which activities must be done first. Very few understand the significance of this exercise [public participation in the IDP]. ... Community education is highly needed. ... People are not well informed about the municipal process concerning service delivery.' (Ward councillor)

Commenting on the capacity of the ward committee, another participant had this to say:

'The ward committee is not capacitated to be public representatives. Most of the questions are based on houses and the people ask about jobs in our municipality.' (Ward councillor)

The practice of discussing issues unrelated to the IDP was echoed by yet another participant: 
'The problem is about jobs. ... People want jobs. I have experienced that the community is always shouting, complaining. ... Some are very angry when they want to raise their issues. ... Some of the issues are never attended to, so it is a longstanding problem.' (Community stakeholder)

These results raise the issue of the need for agency and empowerment in the metropolitan municipality. Sen's (2002:585) conception of process freedom encapsulates agency and empowerment. Empowerment subsumes agency, critical consciousness and transformative social change (Coy et al. 2021:101871; Ferrero y de Loma-Osorio \& Zepeda 2014:29). Narayan (2002:3) identified two components of empowerment. Firstly, the expansion of agency, which conditions opportunity structures for the effective exercise of agency. Secondly, the institutional environment mediates power, accountability, participatory democracy, structuration and capability functionings to ameliorate unfreedom. In Giddens' (1984:14) theorisation, agency is constrained or enabled by social structures. The responses from the focusgroup participants are suggestive of worrying about a lack of empowerment amongst stakeholders. That lack of capacity was raised by a focus-group participant who, for example, said:

'There is a lack of understanding of the meaning of IDP. ... Some think IDP is an ANC branch. ... Sometimes what the stakeholders suggest does not form the content of an IDP. The community is not 'educated' enough to understand the processes of the IDP.... what goes in there and what should be done by other government departments.' (IDP representative forum member)

Capacity challenges were further raised by a focus-group participant who observed:

'Capacity challenges [are an issue]. ... They [community] do not know the process of the IDP, ... they must learn what it is ... so they know what to do when it comes to mayoral roadshows. Some community members do not take public participation in the IDP process seriously, when it is the most important meeting for their future and needs.' (IDP representative forum member)

The core concepts of 'functionings' and 'capability' in Sen's (1999) capability theory emphasise freedoms, citizen agency, justice, inclusion, poverty reduction, efficiency, equity, and resilience (Alkire 2010:28; Sen 2002:585, 2009:139). The study's findings suggest that public representatives could be lacking in the process aspects of capabilities. Similarly, Lyhne, Nielsen and Aaen (2016:320) have established that a lack of skills, knowledge and capacity were constraints impacting public participation spaces. The capabilities of ward committees were, for example, questioned by a focus-group participant, who observed the following with concern:

'The ward committees do not regard themselves as part of the municipality. When the community raises questions, only the ward councillor answers questions. ... They [ward committee members] also want RDP houses and jobs.' (Ward councillor)

This reflects Coelho et al.'s (2021:2) assertion that power can also be associated with the use of resources and that resourcing is a source of relational power. In this regard, power resources from 'structural power' and 'associational power' provide strategic capacity for communities to further their interests (Gavin 2021:6). The power resources and capabilities framework similarly emphasise that specific capabilities, like framing or learning, are needed to mobilise individual power resources, such as network embeddedness, internal solidarity and narrative resources (Gavin 2021:66). Narrative resources constitute a body of interpretive action frames that can be mobilised and deployed to build discursive power (Gavin 2021:6). This means that, done poorly, public participation can result in undemocratic outcomes by reinforcing or perpetuating existing power inequalities, marginalising minority perspectives, creating dysfunctional consensus or fostering cynicism (Sprain 2016:66). This can be the case when public representatives either lack the capabilities to carry out their mandates or the agency to initiate change. This lack of capacity was pointed out by a focus-group participant, who stated:

'Ward councillors forget their responsibilities as they begin to form part of the community and raise complaints and lead the public protests.' (Community stakeholder)

Alkire (2010:37) proposed that in addition to capability expansion, principles such as poverty reduction, durability, sustainability and support for human rights should be integral to human development. Capabilities flourish where there is agency, consciousness and empowerment. Power is related to the ability to guarantee positions of authority or control over resources and the allocation and control of resources are essential elements of power relations (Coelho et al. 2021:4). Declercq and Ayala (2017:4) insightfully explained that power is capacity, potential, ability or wherewithal - it is dynamic and interactional. Similarly, Culley and Angelique (2011:411) observed that discourse and decision-making are nested within systems of power that may mask manipulated and manufactured public consent. As such, public participation in municipal strategic development planning processes is always permeated by power and tactics, strategies and the microphysics of power (Ferrero y de LomaOsorio \& Zepeda 2014:31).

\section{Public participation power dynamics and resource capital}

Public participation draws on the dialectical relationship between authority, influence and power through 'taking part' and 'being part' of the decision-making process (Gyan 2021:2). Power can be the capacity to deny, repress or coerce (Coelho et al.2021:4). Resource constraints often place access limitations on municipal residents who wish to participate. For example, a community member was worried that meetings were held far from where some residents lived, making it difficult for municipal residents to access participation spaces with limited or no resources for transportation. The following quotes capture the sentiments of participants:

'Our areas are far from venues.' (Community stakeholder)

'Sometimes ward committees find it difficult to reach certain areas because the stipend is next to nothing for travelling 
expenses ... They are not capacitated to do consultation and to capture community needs and challenges.' (Community stakeholder)

The issue of a lack of resources was further raised by a participant who lamented:

'... no resources to attend municipal strategic development planning meeting. ... Some do not have money to attend the meetings. ... There is no transport to attend the meeting.' (IDP representative forum member)

On being asked if public participation was inclusive, a participant again pointed to the issue of a lack of resources for accessing such spaces. This suggests that public participation spaces in the metropolitan municipality systematically exclude those community members without their own means of transport for accessing participation platforms and spaces. This was corroborated by a participant who bemoaned the fact that:

'[Because of a] lack of transport, some members can't attend, although interested ... The municipality should budget enough in order to visit the people. The community have the right of say [voice]. The municipality should hire transport for the community to the IDP outreach meetings.' (Community member)

The resource-based theory insightfully provides an analytic framework for discerning situations in which community stakeholders are at a disadvantage concerning others in participation platforms and spaces. Identifying who has authority and control over resources is critical because authority is a means of obtaining resources. Resources may also be accessible to certain influential role players or some actors may lack formal authority but still have essential resources (Coelho et al. 2021:4). Thus, resources determine who participates and a lack thereof sets the agenda favouring more powerful interests (Culley \& Angelique 2011:420). Capital (material, embodied or institutionalised) represents a broad and generalised conception of social power as accumulated resources. In Bourdieu's (1986:241) theorisation, capital is embodied in economic and cultural, social and symbolic forms. Central to Bourdieu's sociology is that society consists of relationships between social agents who dispose of different types of capital, such as economic, cultural, social or political capital. Inclusivity is, therefore, also contingent on actors' access to the resources, institutions and participatory spaces (Chaskin, Khare \& Joseph 2012:864). Power is actualised by the degree of control over the material, human, intellectual and financial resources exercised by different community stakeholders in public participation platforms and spaces. Consequently, Fox-Rogers and Murphy (2013:245) opined that stakeholders' access to the public sphere is contingent upon resource availability, with resource inequities fostering exclusion and elite capture.

\section{Accessing public participation spaces}

The public is a partner in the co-production of public values (Eckerd \& Heidelberg 2020:136).
Meaningful public participation seeks to empower the public through transparency, accountability, enhanced service delivery, equity and inclusiveness (Mbithi, Ndambuki \& Juma 2018:16). Exclusion can stir up feelings of subordination, apathy, self-blame, powerlessness, unworthiness, hostility and anger amongst marginal groups. In governance discourse, subsidiarity emphasises the role of intermediary spaces between local government and residents (Ruiz-Villaverde \& Garcia-Rubio 2017:2484). Subsidiarity facilitates direct democracy by increasing opportunities for citizens to participate in public affairs. Similarly, the pluralist theory of democracy asserts that pluralism and corporatism are ideals to strive for (RuizVillaverde \& Garcia-Rubio 2017:2484).

Notwithstanding the above-mentioned discussion, one crucial power resource is privileged or preferential access to discourse. Elite capture can potentially control the occasion, time, place, setting and the presence or absence of participants in participation platforms and spaces. Where residents access public participation spaces, language, discursive practices and discourse all influence how they put across and articulate their felt needs. This means that social and cultural practices and beliefs may also limit access to public participation spaces. This is because language encodes people's social worlds and allows for systematic and precise analysis of those social worlds (Declercq \& Ayala 2017:4). Language barriers or discursive competencies may thus be both exclusionary and inclusionary. The issue of language and literacy and access to public participation spaces in municipal strategic planning processes also came up as a recurring theme amongst the focus-group participants. A community member raised the following concern:

'Ward committees do not involve the community in their jurisdiction.' (Community member)

\section{Another participant further stated:}

'There is no time to work on ward plans. Time taken in the meeting is too little.' (Community member)

Similarly, another participant echoed the same sentiment:

'They do not give us more time to ask questions or they do not give us chances to talk ... because they are saying we are asking difficult questions.' (Community member)

A ward councillor raised the problem of accessing public participation spaces in the IDP by pointing out:

'We can't raise issues because members of the municipality will be at the meetings.' (Ward councillor)

Reinforcing the concern about the inaccessibility of public participation spaces, a community stakeholder participant had this to say:

'Access is a big issue here ... Let me tell you ... municipal officials are not available to the public. Integrated development plan is not well publicised. Municipality doesn't open communication lines with communities, attendance is another issue. Integrated development plan meetings is [sic] not 
attended as anticipated, only the ward committees and some few residents worry about the IDP outreach meetings.' (Community stakeholder)

In their study, Salehi et al. (2021) have established that structural exclusion barriers are often based on age, with youths often being excluded. When invited, they were expected to participate on terms and settings set by adults. Salehi et al. (2021) have further found that inequalities and opportunities are often constructed and reconstructed within sociocultural, political and economic structures, which empowered or disempowered individuals. Thus, only selected groups in society influence decision-making power through socially legitimised norms for structural theorists. These include, but are not limited to, education, employment, work-life balance, confidence, gender stereotypes, 'glass ceiling' effects and inequitable access to resources/ opportunities, social networking and gendered societal cultures (Salehi et al. 2021:479-480). The relative value placed on different types of expertise and language and the professional assumption about decision-making competence can also make it challenging to hear community voices. For one to become an agent of change, developing consciousness is a prerequisite. Three stages: 'reflection - perception action', constitute the conscientisation process (Ibrahim 2017:10). For Freire ([1968]1972), conscientisation is:

the process in which individuals, not as recipients, but as knowing subjects, achieve a deepening awareness both of the socio-cultural reality which shapes their lives and their capacity to transform that reality. (p. 51)

\section{Perceptions of domination and networking in public participation spaces}

Participatory development structures are often critiqued for reproducing social inequalities within communities (Drydyk 2005:261). The dynamics and sustainability of the conscientisation process are often mediated by several interrelated factors, including individuals' personal traits, self-confidence, educational level, profession, social status and human agency (Ibrahim 2017:11). Thus, the conscientisation process is contingent on various contextual factors and power relations at the individual and community levels (Ibrahim 2017:11). As such, exclusion and delegitimisation exclude certain groups (and their issues) from municipal strategic development planning processes. Agenda-setting power games, as well as visible, invisible and hidden power, thus often shape meanings and values, which define what 'normal' is. Accordingly, unequal power relations are reproduced and determine whose voices are heard in public participation platforms and spaces. Results from focus-group discussions indicated that some residents are excluded during municipal strategic development planning based on their political beliefs and affiliation. This issue of political domination, networking and exclusion was echoed by a ward committee member, who had this to say:
'Politics is a problem here. ... I am not satisfied because my ward community members belong to the other political parties, ... thus there are conflicts. ... This also leads the public to be unwilling to attend IDP meetings.' (Ward committee member)

This response suggests that political cleavages are likely to impact public discourse, decision-making, and access to the participatory public sphere. Constraining issues identified by Nielsen and Aaen (2016:314) may include the value system, histories of marginality, sociopolitical dynamics and power balance. Conflict of interest was raised by a ward councillor who complained:

'The public participants in my ward are always having conflict of interests because of their political affiliations. The process is handled in a manner that alienates the opposition.' (Ward committee member [opposition])

Similarly, Masuku and Macheka (2020:10) had identified situations where communities were used as adornments in preset agendas, making public participation platforms and spaces 'decoration and tokenism'. In such situations, local social structures are exploited for political control (Masuku \& Macheka 2020:13). Within such contexts, public participation inclines towards patronage, associated with political kinships, with political cleavages often working to disempower, exclude and marginalise those considered insignificant others. Zhu and Westphal (2021:625) similarly observed that power typically becomes a property of the natural resource exchange relationship and direct resource dependence relationships. Depoliticisation of public participation spaces was accordingly recommended by a focus-group participant, who had this to say:

'I recommend that the municipality educates the community members to focus on development of the community rather than political interests. They must not be too interested in politics. ... So I can say community needs must not be accepted or rejected based on someone's political affiliation. ... It just raises unnecessary community conflicts and tensions.' (Community stakeholder)

Penderis (2012:10) also observed that exclusion alienates and undermines feelings of identity, belonging and self-worth. It breeds powerlessness, a lack of control, vulnerability and emotional deprivation. Power exhibits itself as ideology (VaneKlasen \& Miller 2006:38) and invisible power often shapes the public's beliefs and sense of self. As such, sociopolitical contexts and political willingness shape the local political frame for public participation practices. With resource limitations, subdued 'community voice', and exclusionary power relations, individuals and communities living at the margins are mostly excluded from participation spaces (Ibrahim 2017:13).

\section{Community commitment and trust in the integrated development plan process and outcomes}

Focus-group participants consistently gave low assessments of trust in public participation spaces. Some participants accused the municipal council of 'hiding information', giving 
out ambiguous or inaccurate information and 'putting a spin' on things or referring to municipal council announcements as 'spin-doctoring'. Thus, concern about the integrity of municipal council officials profoundly came into question. An IDP representative forum member claimed:

'There is lack of commitment and dedication from the ward committees. ... Ward committees struggle to mobilise people during IDP hearings. ... There is poor attendance. ... Not all community members participate. ... I can say the community is not involved in this thing.' (IDP representative forum member)

Another participant complained:

'The public is not given enough time to raise their concerns. ... The challenge is time because these meetings are covered after hours. ... The community need to come very early - around $12 \mathrm{pm}$, not at $5 \mathrm{pm}$.... There is not enough information and time to discuss issues or projects. ... Because of that, few hands are taken.... [There] is little time for questions.' (Ward committee member)

Similarly, another participant raised the following concern:

'We have little time on the day of the IDP outreach meeting. There is just not enough time for the community members to speak at IDP outreach meetings. More time must be given to the stakeholders to voice their concerns. Giving residents positive responses for their concerns will assist in minimising conflict and tensions, which lead to community protests.' (Community stakeholder)

These sentiments from focus-group participants reflect the fact that trust is a critical component of social capital. Bonding social capital is fostered by collaboration amongst actors or community members who take more directive and leading roles in local networks (Vasstrøm \& Normann 2019:853). Network participation nurtures dynamism, which combines 'local and extra-local resources and knowledge to respond to local need' (Bosworth et al. 2015:444). Putman (1993) viewed social capital as 'features of social organisation, such as trust, norms and networks'. Networks of civic engagement facilitate components of social capital-trust, reciprocity and cooperation (Odeyemi \& Skobba 2020:4). Social capital is embedded in relationships and networks and facilitates access to resources and opportunities for individuals and communities (Odeyemi \& Skobba 2020:4). However, the low trust may also suggest that stakeholders do not offer the municipal council expert and professional discretion in planning and policy decisions. Trust deficits affect the strategic choices made by public participation stakeholders on whether to collaborate, with whom to collaborate and to what level. Trust will strengthen community satisfaction within public participation spaces, whereas unequal power relations can undermine and thwart it. Hence, trust is essential for community social cohesion, political and linguistic relations and forms of social capital in local governance (Stein \& Harper 2003:135-136).

\section{Public participation as tokenistic}

For Odeyemi and Skobba (2020:4), decision-making power has to be redistributed to affected communities through a more citizen-centric, responsive, needs-led and efficient form of local governance. Results suggested that public participation in municipal strategic development planning is at best tokenistic, as it is mostly performed for compliance purposes to fulfil legislative and regulatory requirements. A community stakeholder focus-group participant viewed public participation as just a talk show, implying that it was tokenistic. The community stakeholder participant stated:

'You see, for me to participate I need to know what this thing [IDP] is all about ... unavailability of information is a problem. ... IDP outreach is just a talk show, and one is expected to participate?' (Community stakeholder)

Such public participation experiences are typically not transformational (Carvalho, Pinto-Coelho \& Seixas 2016:3). As similarly observed by Nthontho (2017:164), the collaboration, consensus and participatory rhetoric often contrast with the practice of reaching agreements behind closed doors, elite capture and complex power dynamics that exclude less powerful planning actors. Powerful stakeholders thus remain in control over planning decisionmaking processes (Dodge 2009:228). Similarly, Kock and Steiner (2017:170) had established that in many cases, economically powerful and privileged families tend to be disproportionately involved in local politics and play critical roles in controlling local governance structures. Political power was thus also closely interconnected with economic power (Coelho et al. 2021:12).

\section{Community knowledge in municipal strategic development planning}

Public participation as 'popular agency' recognises 'existing capacities of the public as active claims-making agents' (Mohan \& Hickey 2004:3). Human development theory stresses empowerment as a means to social change (Boni \& Gasper 2012:458). Empowerment and transformation encapsulate popular agency. Findings indicated that public participation in municipal strategic development planning was often undermined by low levels of literacy, a lack of a sense of agency, public apathy, access disincentives, time costs, disproportionately high respect for political authority, negative past experiences with public participation spaces, participation fatigue and communication gaps. This suggests that public participation is often tokenistic, especially in communities with high poverty levels, weak representative institutions, insufficient resources and other sociopolitical power relational constraints to developmental local government. The findings from focus-group participants provided evidence for this view. A ward councillor, for example, had this to say:

'No, I am not satisfied with public participation in the IDP in this metropolitan municipality. I feel that people's opinions are not well informed about the IDP.... People need to be more educated.' (Ward councillor)

A ward committee member expressed frustration by pointing out:

'The public is uneducated and excluded in strategic development planning.' (Ward committee member) 
These results point to frustrations with public participation spaces in the municipal strategic development planning processes. Findings also indicate that residents often drifted away from the constitutional edicts of the South African local government, as enshrined in terms of Part B of Schedule 4 and Part B of Schedule 5 of the Constitution (RSA 1996). Section 156(5) of the Constitution (RSA 1996) further provides that municipalities have the incidental right to exercise any power concerning a matter reasonably necessary for or incidental to the effective performance of their function to the extent set out in Section 155(6)(a)(7) (RSA 1996). Without being empowered with knowledge about municipal strategic development planning, deficits in capabilities and functionings may translate into social injustice and attendant reproduction of inequality and exclusion. As such, public participation power dynamics may continue to mediate municipal strategic development planning outcomes in ways that marginalise less powerful interests.

Therefore, this means that whilst on the surface public participation may appear inclusive of a range of stakeholders, powerful or elite interests (elite capture) shape development planning outcomes, with less powerful interests largely being marginalised or unheard altogether (Culley \& Angelique 2011:422). Also, whilst power relations 'are not immutable in form or content', they work to generate the 'maintenance, cultivation and reproduction' of existing power relations (Flyvbjerg 1998:231). Experiences of symbolic violence amongst public participation stakeholders manifest as feelings of being out of place, anxiousness, awkwardness and shame, as well as feeling stupid and powerless. In this regard, symbolic violence is structurally constructed (Samuel 2013:402).

\section{Representations versus marginalisation and powerlessness}

Public participation in municipal strategic development planning can potentially be for manipulative purposes, through co-option and concealing means of maintaining power relations (Cornwall \& Brock 2005:1046). Leal (2007:539) ascribed the manipulation and co-option of public participation spaces to the interests of a neo-liberalist policy agenda. Leal (2007:539) contended that public participation's political decapitation is because of its dislocation from its radical Freirean roots. Examining the dynamics of power relations, the influence of structures on social action and the role of social capital in producing and reproducing inequality affords public administrators a potent analytical lens through which to view and comprehend the complex power dynamics of local governance-community relations. Bourdieu (1989:16) insightfully explained that the 'visible' often masks and hides the 'invisible', which determines it, and as a result, the 'truth' is never fully revealed to the observer. Concerning public participation power dynamics in municipal strategic development planning, findings from focus-group participants exhibited the views discussed here. A member of the IDP representative forum indicated:
'... public participation in the IDP does not adequately involve the community as stakeholders. ... They [municipal council] only report what they have already done, ... the public is excluded and uninformed about participation in the IDP, also the public is not educated enough. ... A lot of people don't attend these IDP meeting because really, at the end of the day, their views are not considered ... so why bother? ... Those who do come, don't get [the] opportunity to speak.' (IDP representative forum member)

This suggests that public participation in the metropolitan municipality is the result of social practices ordered across spaces, which can be 'continually repeated or recursive, reproducing the conditions that make these activities possible' (Giddens 1984:2). Knowledge enables 'reflexive ordering and reordering of social relations, which impact actions and behaviour of individuals and groups' (Giddens 1984:16). The implication is that power as agency is a reflection of capability, not intentions, and it is the exertion of power that creates an effect and impact. A further implication is that structures in the local government system enable public participation stakeholders to reproduce social systems, which also function as a mode of control. Platforms and spaces of public participation are thus centres of meaning, expressions of intentions and aspirations constructed by human experience, either at the micro space (personal) level or macro space (municipal) level. Conversely, exclusion undercuts identity, belonging and self-worth (Penderis 2012:10). Institutionalised structures can thus be essentially 'closed' public sphere spaces.

Findings of this study consistently show that certain voices and perspectives appear too often to be excluded from development planning processes. As alluded to by Sprain (2016:70), entitlements are conferred upon participants by those who already hold specific power or status. Evidence from focus-group participants, for example, supports this view, where participants had this to say:

'The municipality should put the people's needs and value their
views. The stakeholders should treat us as the same.... Financial
power gives advantage to those with money and I think culture
as well ... cultural because of my age [my] opinion may not
count. ... I don't get listened to ... and it is frustrating.'
(Community stakeholder)

Similarly, Mangai (2016:90) had established that individuals are likely to be marginalised and excluded based on their gender, age, values, socio-economic background and experiences. This was similarly reinforced by a community stakeholder who dejectedly pointed out:

'Because I don't have much powers to be heard, maybe because of my age. ... I think only certain people's opinions matter. ... Not easy to participate where you are not recognised. ... We don't get the chance to talk, ... no chance to speak.' (Community stakeholder)

Thus, in Foucault's theorisation of relational power and its inextricable link to knowledge, power dynamics shape participatory spaces (Foucault 1978:93). Certain powerful people maintain their influence by controlling who gets to 
the decision-making table and what is put on the agenda. These dynamics exclude and devalue the concerns and representation of less powerful groups (VaneKlasen \& Miller 2006:39) by excluding some voices and issues from getting a fair hearing. Public participation spaces interact dynamically, constantly opening and closing through struggles for legitimacy and resistance, co-option and confrontation and are thus never static or devoid of social relations. Public participation platforms allow elected and appointed municipal public officials and residents to exercise democratic citizenship in the public sphere through collaboration, deliberation, co-production and co-creation. However, such spaces reflect particular contexts and traces of histories of governance, structuration and institutional cultures and practices, which shape relations and rules of engagement and limit opportunities for the enactment of citizenship (Cornwall 2004:2). Stakeholders lacking in resources, voice or legitimacy are often left out of participatory spaces (Coelho et al. 2021:23).

\section{Conclusion and implications for local governance}

Whilst stakeholders could benefit from public participation in municipal strategic development planning processes, many stakeholders and communities remain powerless because of exclusionary power dynamics in local governance (Odeyemi \& Skobba 2020:3). Public participation is intimately associated with power, agency, empowerment and the need to include mainly the marginalised in decision-making processes. Power thus impacts 'community voice'. However, dealing with public participation power dynamics is a complex process that requires agency and critical consciousness. Such consciousness is meant to empower communities and capacitate stakeholders. They become fully cognisant of how power structures emerge and how powerless stakeholders can be afforded meaningful public participation.

This study's results indicated mixed views regarding participants' satisfaction with public participation in municipal strategic development planning processes in the case study of a metropolitan municipality. Whilst public participation is generally perceived as the opening of the civic, political and co-governance structures and as a platform and space for providing access to policy agendas and responses, qualitative data in this article suggest that in reality these forms of empowerment might be more symbolic than meaningful. Residents were often deficient in requisite knowledge on the strategic nature of municipal strategic development planning processes and, as such, lacked the essential capabilities, competences, freedoms and functionings for meaningfully exercising 'community voice' in public participation platforms and spaces. Municipal residents were also often discouraged from participating in strategic development planning because of the size and incomprehensibility of the integrated development planning documents. This was compounded by inadequate knowledge, capacity and capability; resource constraints and language barriers, all of which further disempowered, marginalised and excluded residents from meaningfully participating and articulating community priorities and needs.

Furthermore, results indicated that some residents were excluded based on their political beliefs and affiliation. The researchers therefore generally conclude that public participation power dynamics shape municipal strategic development planning process review outcomes in the metropolitan municipality under study in multiple and complex ways that marginalise and exclude less powerful community voices. A systematic failing or neglect to include and empower stakeholders who are less interested in local governance, less civically active and more cynical of participatory governance may further aggravate the tokenistic nature of public participation, consequently undermining the legitimacy and democratic values of public participation spaces. Based on a synthesis of extant available related literature and study findings, this article thus proposes a local governance framework for enhancing community voice during public participation in municipal strategic development planning processes (Figure 1).

In Figure 1, a local governance framework is proposed for enhancing community voice in public participation platforms and spaces in municipal strategic development planning processes in local government. Municipalities could enhance community voice during public participation by empowering, capacitating and conscientising stakeholders. The vehicle for such empowerment, capacitation and conscientisation include

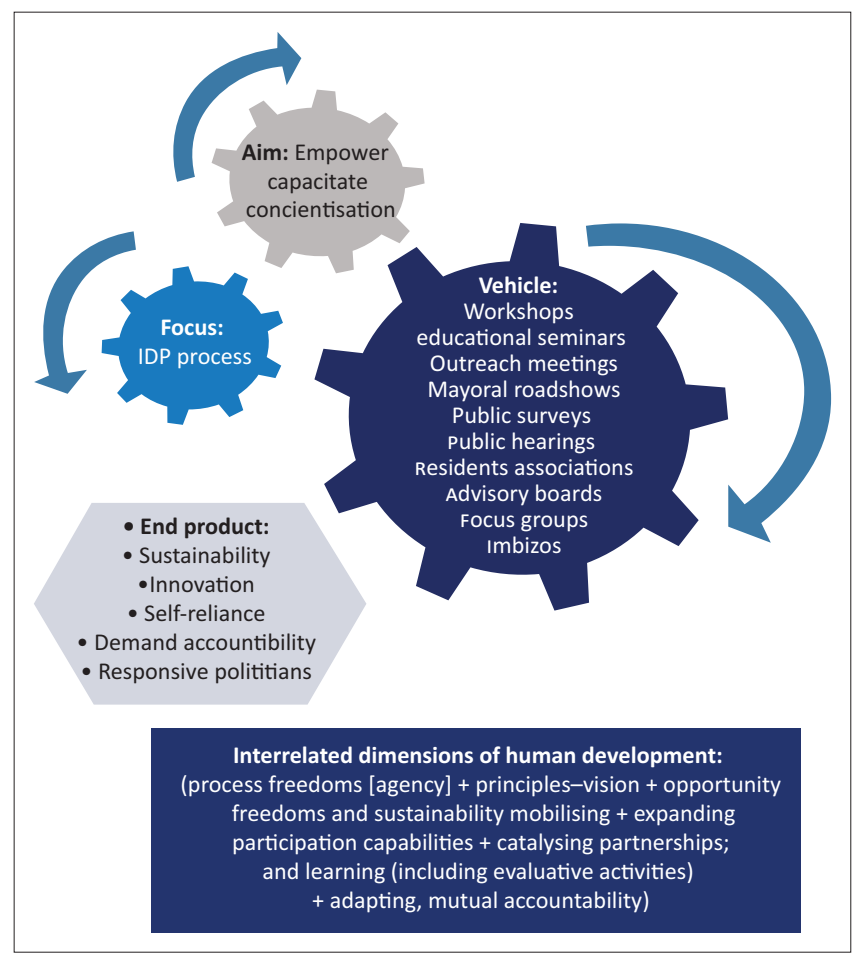

FIGURE 1: A local governance framework for enhancing community voice in public participation platforms and spaces. 
workshops, educational seminars, mayoral roadshows, public surveys, public hearings, residents associations, advisory boards, focus groups, imbizos, interactive social media (Facebook, WhatsApp) and m-Government.

To exercise voice, communities will need to be empowered through resources, organisational capacity (ward committees) and 'community wiring' (connectedness, inclusiveness and social cohesion). Community empowerment may help develop skills and confidence (for community self-help). Communities become strong when individuals have a free and fair say in decisions that affect them. Community empowerment may be built from community organiser initiatives, where communities are trained and supported to listen to concerns, to build relationships and networks and to help people take community action on local issues that matter to them, thereby reducing bureaucracy and devolving power to communities. With a focus on changing public sector culture towards a more participative ethos, municipalities should leverage interactive social media (Facebook, WhatsApp) and m-Government to empower residents through participatory democracy and co-creation of municipal strategic plan outputs and outcomes responsive to community needs.

These strategies must be guided and buttressed by the interrelated dimensions of human development: process freedoms (agency) - public value principles, critical consciousness, developmental local government vision opportunity freedoms and sustainability mobilising. This, in essence, could directly lead to and result in the expansion of public participation capabilities - catalysing social networks, social capital and partnerships through learning (consciousness, including evaluative activities and social change) - contextual adaptation, mutual collaboration, co-creation and accountability. Participatory governance spaces should more robustly encapsulate human rights and freedoms and access opportunities and enhance capabilities and functionings in the community. Strong communities need capital resources, social capital and human capabilities in the form of skilled, knowledgeable, confident conscientised community members embodying human agency. A rights-based approach to developmental local government must focus on conscientising communities on political issuessuch asinequality, constitutional rights, exclusion, power imbalances, accountability and relationships inherent in structures of society and local governance systems. It also goes without saying that resource availability has overarching implications for community development, empowerment and agency.

In conclusion, it is argued that public participation in municipal strategic development planning in the metropolitan municipality under study is at best 'decorative and tokenistic'. It might simply serve the purpose of fulfilling legislative and regulatory requirements for purposes of compliance. Furthermore, public participation in the metropolitan municipality remains mostly tokenistic, constituting mere 'window dressing', co-option and 'pretence' of inclusion of the marginalised in public participation platforms and spaces. The researchers infer that such tokenism amounts to little more than a cosmetic smokescreen to gain approval of pre-designed plans from passive beneficiaries, with power mainly remaining in the hands of the municipal council and elected and appointed public officials. This suggests that on the surface, public participation in municipal strategic development planning in the metropolitan municipality appears inclusive of a range of stakeholders who claim a stake in municipal planning. However, at best, powerful or elite interests primarily shape strategic development planning outcomes.

This study had some limitations that prevent the generalisation of the findings. The conclusions of this study were purely based on inferences made from available data. In addition, the qualitative research method used in this study could shed some light on critical findings, but it cannot represent the whole population. The findings may, however, be transferable to similar contexts in South Africa and elsewhere. This study was limited to 34 participants who participated in four focusgroup discussions. For this reason, the findings may not fully represent the beliefs, perceptions or views of the whole population of people who participate in the IDP process. In future studies, the scope of sampling should be extended to include the opinions of municipal authorities (both elected and appointed public officials) in directorates that closely relate to public participation in the IDP review process, especially those from the IDP/Budget/Performance Management System (PMS) Unit and the IDP Organisational Performance Management Portfolio Committee. Given that the IDP is a multisectoral/multidimensional planning document requiring input from various stakeholders during its development process, future research could also sample key sector departments.

\section{Acknowledgements Competing interests}

The authors declare that they have no financial or personal relationships that may have inappropriately influenced them in writing this article.

\section{Authors' contributions}

M.M.S. conceptualised the study, compiled the literature review, collected the data and performed the write-up for this article. L.L. assisted with conceptualising the study, provided commentary, assisted with the research problem and analysing the data. This article was partly extracted from M.M.S's PhD Thesis, which was completed under the supervision of L.L.

\section{Ethical considerations}

Approval for this study was sought from the University of the Free State and all applicable ethical protocols were followed under the supervision of the co-author Prof. Liezel Lues. 


\section{Funding information}

This research received no specific grant from any funding agency in the public, commercial or not-for-profit sectors.

\section{Data availability}

Data sharing is not applicable to this article as no new data were created or analysed in this study.

\section{Disclaimer}

The views and opinions expressed in this article are those of the authors and do not necessarily reflect the official policy or position of any affiliated agency of the authors.

\section{References}

Alkire, S., 2010, Human development: Definitions, critiques, and related concepts, Human Development Research Paper 2010/01, United Nations Development Programme (UNDP), New York, NY

Arnstein, S., 1969, 'A ladder of participation', Journal of the American Planning Association 35(4), 216-244. https://doi.org/10.1080/01944366908977225

Auriacombe, C., 2015, Course code: PMG 2A11: Public financial management: Internal handbook, University of Johannesburg, Johannesburg.

Babbie, E., 2016, The practice of social research, 14th edn., Cengage Learning, Boston, MA.

Bakewell, O., 2010, 'Some reflections on structure and agency in migration theory', Journal of Ethnic and Migration Studies 36(10), 1689-1708. https://doi.org/10.10 80/1369183X.2010.489382

Barron, A., 2005, 'Foucault and law', in J. Penner, D. Schiff \& R. Nobles (eds.) Introduction to Jurisprudence and legal theory: Commentary and materials, pp. 955-1034, Oxford University Press, Oxford.

Barthes, R., [1957]1972, Mythologies, transl. A. Lavers, Paladin, London.

Bernhardt, Y., 2015, Section A: Public policy management, Internal handbook, University of Johannesburg, Johannesburg.

Bevir, M., 2011, 'Public administration as storytelling', Public Administration 89(1), 183-195. https://doi.org/10.1111/j.1467-9299.2011.01908.x

Bevir, M., 2013, A theory of governance, University of California Press, Berkeley, CA.

Blaikie, N., 2007, Approaches to social enquiry: Advancing knowledge, Polity Press, London.

Bless, C., Higson-Smith, C. \& Sithole, S.L., 2013, Fundamentals of social research methods: An African perspective, 5 th edn., Juta, Cape Town.

Boni, A. \& Gasper, D., 2012, 'Rethinking the quality of universities: How can human development thinking contribute?', Journal of Human Development and Capabilities 13(3), 451-470. https://doi.org/10.1080/19452829.2012.679647

Bosworth, G., Annibal, I., Carroll, T., Price, L., Sellick, J. \& Shepherd, J., 2015, 'Empowering local action through neo-endogenous development: The case of LEADER in England', Sociologia Ruralis 56(3), 427-449. https://doi.org/10.1111/ soru.12089

Bourdieu, P., 1986, 'The forms of capital', in J.G. Richardson (ed.), Handbook of theory and research for the sociology of education, pp. 241-258, Greenwood Press, New York, NY

Bourdieu, P., 1989, 'Social space and symbolic power', Sociological Theory 7(1), 14-25. https://doi.org/10.2307/202060

Bozeman, B., 2007, Public values and public interest: Counterbalancing economic individualism, Georgetown University Press, Washington, DC.

Buccus, I., 2021, 'Rebuilding active public participation after the COVID-19 era: The South African case', Journal of Public Affairs e2720. https://doi.org/10.1002/ pa.2720

Bulley, D. \& Sokhi-Bulley, B., 2014, 'Big society as big government: Cameron's governmentality agenda', British Journal of Politics and International Relations 16 452-470. https://doi.org/10.1111/j.1467-856X.2012.00547.x

Carvalho, A., Pinto-Coelho, Z. \& Seixas, E., 2016, 'Listening to the public - Enacting power: Citizen access, standing and influence in public participation discourses', Journal of Environmental Policy and Planning 21(5), 563-576. https://doi.org/ 10.1080/1523908X.2016.1149772

Chaskin, R., Khare, A. \& Joseph, M., 2012, 'Participation, deliberation, and decision making: The dynamics of inclusion and exclusion in mixed-income developments' Urban Affairs Review 48(6), 863-906. https://doi.org/10.1177/1078087412450151

Christensen, H.E. \& McQuestin, D., 2019, 'Community engagement in Australian local governments: A closer look and strategic implications', Local Government Studies 45(4), 453-480. https://doi.org/10.1080/03003930.2018.1541794

Coelho, T.R., Pozzebon, M. \& Cunha, M.A., 2021, 'Citizens influencing public policymaking: Resourcing as source of relational power in e-participation platforms', Information Systems Journal 1-33. https://doi.org/10.1111/isj.12359
Cohen, L., Manion, L. \& Morrison, K., 2018, Research methods in education, 8th edn., Routledge, London.

Cornwall, A., 2004, 'New democratic spaces? The politics and dynamics of institutionalised participation', IDS Bulletin 35(2), 1-10. https://doi. org/10.1111/j.1759-5436.2004.tb00115.x

Cornwall, A., 2016, 'Women's empowerment: What works?', Journal of Internationa Development 28(3), 342-359. https://doi.org/10.1002/jid.3210

Cornwall, A. \& Brock, K., 2005, 'What do buzzwords do for development policy? A critical look at "participation," "empowerment" and "poverty reduction"', Third World Quarterly 26(7), 1043-1060. https://doi.org/10.1080/01436590500235603

Cooper, T.L., 2005, 'Civic engagement in the twenty-first century: Toward a scholarly and practical agenda', Public Administration Review 65(5), 534-535. https://doi. org/10.1111/j.1540-6210.2005.00480.x

Cozier, Z. \& Witmer, D.F., 2001, 'The development of a structuration analysis of new publics in an electronic environment', in R.L. Heath (ed.), Handbook of public relations, pp. 615-623, Sage, Thousand Oaks, CA

Coy, D., Malekpour, S., Saeri, A.K. \& Dargaville, R., 2021, 'Rethinking community empowerment in the energy transformation: A critical review of the definitions, drivers and outcomes', Energy Research \& Social Science 72, 101871. https://doi. org/10.1016/j.erss.2020.101871

Creswell, J.W., 2007, Qualitative inquiry and research design: Choosing among five approaches, Sage Publications, Thousand Oaks, CA.

Creswell, J.W. \& Creswell, J.D., 2018, Research design: Qualitative, quantitative and mixed methods approaches, 5th edn., Sage, Los Angeles, CA.

Culley, M.R. \& Angelique, H., 2011, 'Participation, power, and the role of community psychology in environmental disputes: A tale of two nuclear cities', American Journal of Community Psychology 47(3-4), 410-426. https://doi.org/10.1007/ s10464-010-9395-9

Curry, L., Nembhard, I. \& Bradley, E., 2009, 'Qualitative and mixed methods provide unique contributions to outcomes research', Circulation 119(10), 1442-1452. https://doi.org/10.1161/CIRCULATIONAHA.107.742775

Declercq, J. \& Ayala, A.A., 2017, "Examining "elite" power dynamics in informantresearch relations and its impact on ethnographic data construction: A case study from pharmaceutical health communication', International Journal of Qualitative Methods 16, 1-12. https://doi.org/10.1177/1609406917704137

Dodge, J., 2009, 'Environmental justice and deliberative democracy: How social change organisations respond to power in the deliberative system', Policy and Society 28(3), 225-239. https://doi.org/10.1016/j.polsoc.2009.08.005

Drydyk, J., 2005, 'When is development more democratic?', Journal of Human Development 6(2), 247-267. https://doi.org/10.1080/14649880500120566

Durham, F., 2005, 'Public relations as structuration: A prescriptive critique of the StarLink Global Food Contamination Case', Journal of Public Relations Research 17(1), 29-47. https://doi.org/10.1207/s1532754xjprr1701_4

Easterby-Smith, M., Thorpe, R. \& Jackson, P., 2008, Management research, 3rd edn., Sage, London.

Eckerd, A. \& Heidelberg, R.L., 2020, 'Administering public participation', American Review of Public Administration 50(2), 133-147. https://doi. org $/ 10.1177 / 0275074019871368$

Esmark, A., 2018, 'Limits to liberal government: An alternative history of governmentality', Administration \& Society 50(2), 40-268. https://doi. org/10.1177/0095399715587521

Ferrero y de Loma-Osorio, G. \& Zepeda, C.S., 2014, 'Rethinking development management methodology: Towards a "process freedoms approach"', Journal of Human Development and Capabilities 15(1), 28-46. https://doi.org/10.1080/194 52829.2013.877425

Finlay, R. \& Hopkins, P., 2019, 'Resistance and marginalisation: Islamophobia and the political participation of young Muslims in Scotland', Social and Cultura Geography 21(4), 546-568. https://doi.org/10.1080/14649365.2019.1573436

Flyvbjerg, B., 1998, Rationality and power: Democracy in practice, transl. S. Sampson, Chicago University Press, Chicago, IL.

Foucault, M., 1978, The history of sexuality, Vintage Books, New York, NY.

Foucault, M., 1982, 'The subject and power', Critical Inquiry 8(4), 777-795. https:// doi.org/10.1086/448181

Foucault, M., 1990, The history of sexuality, vol. 2, Vintage Books, New York, NY.

Foucault, M., 1991, 'Governmentality', in G. Burchell, C. Gordon \& P. Miller (eds.), The Foucault effect: Studies in governmentality, pp. 87-104, Harvester Wheatsheaf, London.

Foucault, M., 2002, Power: Essential works of Foucault 1954-1984, vol. 3, Penguin Books, London.

Foucault, M., 2007, Security, territory, population: Lectures at the Collège de France 1977-1978, Palgrave, London.

Foucault, M., 2019, Subjectivity and truth: Lectures at the Collège de France 1980-1981, Picador, London.

Fouche, C.B., Strydom, H. \& Roestenburg, W.J.H. (eds.), 2021, Research at the grassroots: For the social sciences and human services professions, 5th edn., Van Schaik Publishers, Pretoria.

Fox-Rogers, L. \& Murphy, E., 2013, 'Informal strategies of power in the local planning system', Planning Theory 13(3), 244-268. https://doi.org/ 10.1177/1473095213492512

Frederickson, H.G., 1980, New public administration, University of Alabama Press, Tuscaloosa, AL. 
Freire, P., [1968]1972, Pedagogy of the oppressed, transl. M. Bergman Ramos, Herder, New York, NY.

Fung, A., 2003, 'Recipes for public spheres: Eight institutional design choices and their consequences', Journal of Political Philosophy 11(3), 338-367. https://doi. org/10.1111/1467-9760.00181

Gammage, S., Kabeer, N. \& Van der Meulen Rodgers, Y., 2016, 'Voice and agency: Where are we now?', Feminist Economics 22(1), 1-29. https://doi.org/10.1080/ 13545701.2015.1101308

Gaventa, J., 2006, Power after Lukes: A review of the literature, Institute of Development Studies, Brighton.

Gaventa, J. \& Valderrama, C., 1999, 'Participation, citizenship and local government', paper prepared for workshop on 'Strengthening Participation in Local Governance', Institute of Development Studies, University of Sussex, Brighton, 21-24 June.

Gavin, M., 2021, 'Reframing the narrative: Renewing power resources and capabilities in union campaigns for public education', Journal of Industrial Relations $0(0)$ 1-24. https://doi.org/10.1177/00221856211000405

Giddens, A., 1976, New rules of sociological method: A positive critique of interpretive sociology, Basic Books, New York, NY.

Giddens, A., 1984, The constitution of society: Outline of the theory of structuration, University of California Press, Berkeley, CA.

Gordon, C., 1991, 'Governmental rationality: An introduction', in G. Burchell, C. Gordon \& P. Miller (eds.), The Foucault effect: Studies in governmentality, pp. 1-52, Harvester Wheatsheaf, Hemel Hempstead.

Gyan, C., 2021, 'Community development participation scale: A development and validation study', Community Development 52(4), 459-472. https://doi.org/ 10.1080/15575330.2021.1885049p.2

Habermas, J., 1996, Between facts and norms, Polity, Cambridge.

Hildebrand, M. \& Martell, C.L., 2012, 'The negation of power: From structuration theory to the politics of the Third Way', Distinktion: Scandinavian Journal of Socia Theory 13(2), 187-207. https://doi.org/10.1080/1600910X.2012.687694

Hooks, B., 1989, 'Choosing the margin as a space of radical openness', in B. Hooks (ed.), Yearning: Race, gender, and cultural politics, pp. 203-209, South End Press, Boston, MA.

Ibrahim, S., 2017, 'How to build collective capabilities: The 3C-model for grassroots-led development', Journal of Human Development and Capabilities 18(2), 1-26. https:// doi.org/10.1080/19452829.2016.1270918

Ibrahim, S. \& Alkire, S., 2007, 'Agency and empowerment: A proposal for internationally comparable indicators', Oxford Development Studies 35(4), 379-403. https://doi. org/10.1080/13600810701701897

James, O., 2009, 'Evaluating the expectations disconfirmation and expectations anchoring approaches to citizen satisfaction with local public services', Journal of Public Administration Research and Theory 19(1), 107-123. https://doi. org/10.1093/jopart/mum034

Källström, L., Mauro, S., Sancino, A. \& Grossi, G., 2020, 'The governance games of citizens and stakeholders' engagement: Longitudinal narratives', Local Government Studies 47(2), 1-27. https://doi.org/10.1080/03003930.2020.1807340

Kaya, A., 2014, 'Islamophobia', in J. Cesari (ed.), The Oxford handbook of European Islam, pp. 745-769, Oxford University Press, Oxford.

Kezar, A., 2011, 'Grassroots leadership: Encounters with power dynamics and oppression', International Journal of Qualitative Studies in Education 24(4), 471-500. https://doi.org/10.1080/09518398.2010.529848

Khan, M.R. \& Ara, F., 2006, 'Women, participation and empowerment in local government: Bangladesh union Parishad perspective', Asian Affairs 29(1), 73-92.

Kim, J., 2021, 'Rethinking public administration and the state: A Foucauldian governmentality perspective', International Review of Public Administration 26(2) 75-191. https://doi.org/10.1080/12294659.2021.1889102

Kock, F. \& Steiner, L.M.S., 2017, 'Participation without power: The failure of citizen participation in Barranguilla', Latin American Perspectives 44(2), 168-183. https:// doi.org/10.1177/0094582X16668312

Koens, C. \& Gunawardana, S.J., 2021, A continuum of participation: Rethinking Tamil women's political participation and agency in post-war Sri Lanka', Internationa Feminist Journal of Politics 23(3), 463-484. https://doi.org/10.1080/14616742.20 20.1734043

Landemore, H., 2017, 'Deliberative democracy as open: Not just representative democracy', Daedalus 146(3), 1-13. https://doi.org/10.1162/DAED_a_00446

Leal, P., 2007, 'Participation: The ascendancy of a buzzword in the neo-libera era', Development in Practice 17(4), 539-548. https://doi.org/10.1080/ 09614520701469518

Lues, L., 2014, 'Citizen participation as a contributor to sustainable democracy in South Africa', International Review of Administrative Sciences 80(4), 802-804. https://doi.org/10.1177/0020852314533450

Lyhne, I., Nielsen, H. \& Aaen, S.B., 2016, 'What determines the substantive influence of public participation? An investigation of planners' views on conditions for participatory practices in Denmark', Planning Practice and Research 31(3), 311-326. https://doi.org/10.1080/02697459.2016.1174970

Machin, A. \& Ruser, A., 2021, 'Corporealising a healthy democracy? Inequality, bodies and participation', Representation 57(2), 1674912. https://doi.org/10.1080/ 00344893

Makiva, N., Bob, T. \& Davids, G., 2021, 'Efficacy of public participation prior to installation of portable toilets in South Africa: A case of Makhaza area in Cape Town, Western Cape Province', African Journal of Public Affairs 12(1), 171-187.
Mangai, M.S., 2016, 'The dynamics of failing service delivery in Nigeria and Ghana' IASIA E-Journal: Developments in Administration 1(1), 81-111. https://doi. org/10.46996/dina.v1i1.5101

Mankuebe, K. \& Manicom, D., 2020, 'Public participation in public policy making: The case of the Lesotho National Decentralisation Policy', Journal of Public Administration 55(3), 370-384.

Maree, K. (ed.), 2007, First steps in research, 1st edn., Van Schaik Publishers, Pretoria.

Maree, K., Creswell, J.W., Ebersöhn, L., Eloff, I., Ferreira, R., Ivankova, N.V. et al. (eds.), 2016, First steps in research, 2nd edn., Van Schaik Publishers, Pretoria.

Masuku, S. \& Macheka, T., 2020, 'Policy making and governance structures in Zimbabwe: Examining their efficacy as a conduit to equitable participation (inclusion) and social justice for rural youths', Cogent Social Sciences 7, 1855742 https://doi.org/10.1080/23311886.2020.1855742

Mbithi, A., Ndambuki, D. \& Juma, F.O., 2018, 'Determinants of public participation in Kenya county governments', Journal of Asian and African Studies 54(2), 1-18. https://doi.org/10.1177/0021909618794028

McGarry, O., 2016, "Knowing "how to go on": Structuration theory as an analytical prism in studies of intercultural engagement', Journal of Ethnic and Migration Studies 42(12), 2067-2085. https://doi.org/10.1080/136918 3X.2016.1148593

McKinlay, A., Carter, C. \& Pezet, E., 2012, 'Governmentality, power and organization', Management and Organizational History 7(1), 3-15. https://doi.org/10.1177/ Management and
1744935911429414

Mohan, G. \& Hickey, S., 2004, 'Relocating participation within a radical politics of development: Critical modernism and citizenship', in S. Hickey \& G. Mohan (eds.) Participation: From tyranny to transformation, Zed Books, London, New York, NY.

Moore, M.H., 2013, Recognising public value, Harvard University Press, Cambridge, MA.

Munyinda, N.S. \& Habasonda, L.M., 2013, Public participation in Zambia. The case of natural resources management, Danish Institute for Human Rights, Lusaka.

Murambo, T., 2008, 'Beyond public participation: The disjuncture between South Africa's environment impact assessment law and sustainable development', Potchefstroom Electronic Journal 11(3), 124-127. https://doi.org/10.4314/pelj. v11i3.42238

Narayan, D., 2002, Empowerment and poverty reduction: A sourcebook, World Bank, Washington, DC.

Nielsen, L.H. \& Aaen, S.B., 2016, 'What determines the substantive influence of public participation? An investigation of planners' views on conditions for participatory practices in Denmark', Planning Practice and Research 31(3), 311-326. https:// doi.org/10.1080/02697459.2016.1174970

Nikku, B.R. \& Rafique, Z., 2019, 'Empowering people: Role for political social work in South Asia', International Social Work 62(2), 877-891. https://doi. org/10.1177/0020872818755861

Nowell, L.S., Norris, J.M., White, D.E. \& Moules, N.J., 2017, 'Thematic analysis: Striving to meet the trustworthiness criteria', International Journal of Qualitative Methods 16(1), 1-13. https://doi.org/10.1177/1609406917733847

Nthontho, M.A., 2017, 'Unleashing student potential through democratic participation in decision making: Controversies and prospects', Africa Education Review in decision making: Controversies and prospects', Africa Educa
$14(3-4), 158-174$. https://doi.org/10.1080/18146627.2017.1279013

Odeyemi, E. \& Skobba, K., 2020, 'Who is at the table? Civic engagement in small town housing decision-making', Local Government Studies 47(6), 1014-1036. https:// doi.org/10.1080/03003930.2020.1864334

Oni, S., Oni, A.A., Ibietan, J. \& Deinde-Adedeji, G.O., 2020, 'E-consultation and the quest for inclusive governance in Nigeria', Cogent Social Sciences 6(1), 1823601. https://doi.org/10.1080/23311886.2020.1823601

Ospina, S.M., Esteve, M. \& Lee, S., 2018, 'Assessing qualitative studies in Public Administration research', Public Administration Review 78(4), 593-605. https:// doi.org/10.1111/puar.12837

Pandeya, G.P., 2015, 'Does citizen participation in local government decision-making contribute to strengthening local planning and accountability systems? An empirical assessment of stakeholders' perceptions in Nepal', International Public Management Review 16(1), 67-98.

Parvin, P., 2021, 'The participatory paradox: An egalitarian critique of participatory democracy', Representation 57(2), 263-285. https://doi.org/10.1080/00344893.2 020.1823461

Pateman, C., 1975, Participation and democratic theory, Cambridge University Press, Cambridge.

Pateman, C., 2012, 'Participatory democracy re-visited', Perspectives on Politics 10(1) 7-19. https://doi.org/10.1017/S1537592711004877

Penderis, S., 2012, 'Theorising participation: From tyranny to emancipation', The Journal of African and Asian Local Government Studies 3(1), 1-28.

Polkinghorne, D.E., 2005, 'Language and meaning: Data collection in qualitative research', Journal of Counseling Psychology 52(2), 137-145. https://doi. org/10.1037/0022-0167.52.2.137

Przeybilovicz, E., Cunha, M.A, Geertman, Leleux, S.C., Michels, A., Tomor, Z. et al. 2020, 'Citizen participation in the smart city: Findings from an international comparative study', Local Government Studies 1-25. https://doi.org/10.1080/030 03930.2020.1851204

Putman, R., 1993, Making democracy work: Civic traditions in modern Italy, Princeton University Press, Princeton, NJ.

Republic of South Africa (RSA), 1996, The Constitution of the Republic of South Africa, Government Printer, Pretoria. 
Rolfe, S., 2016, 'Divergence in community participation policy: Analysing localism and community empowerment using a theory of change approach', Local Government community empowerm
Studies $42(1), 97-118$

Ruiz-Villaverde, A. \& Garcia-Rubio, M.A., 2017, 'Public participation in European water management: From theory to practice', Water Resources Management 31 2479-2495. https://doi.org/10.1007/s11269-016-1355-1

Rutgers, M.R., 2015, 'As good as it gets? On the meaning of public value in the study of policy and management', American Review of Public Administration 45(1), 29-45.

Salehi, A., Whitehead, D., Sebar, B., Upadhyay, R., Coyne, E. \& Harris, N., 2021, 'Young women living in Iran: Gendered drivers influencing social participation and wellbeing', Journal of Gender Studies 30(4), 478-495. https://doi.org/10.1080/09 589236.2020.1868982

Samuel, C., 2013, 'Symbolic violence and collective identity: Pierre Bourdieu and the ethics of resistance', Social Movement Studies 12(4), 397-413. https://doi.org/10 $.1080 / 14742837.2013 .823345$

Schwandt, T.A., 2001, Dictionary of qualitative inquiry, 2nd edn., Sage, London.

Sen, A., 1999, Development as freedom, Oxford University Press, Oxford.

Sen, A., 2002, Rationality and freedom, Belknap, Cambridge.

Sen, A., 2009, The idea of justice, Harvard University Press, Cambridge, MA.

Sewell, W.H., 2005, Logics of history: Social theory and social transformation, University of Chicago Press, Chicago, IL.

Sibanda, M.M. \& Lues, L., 2019, 'Public participation in integrated development planning: A case of the Buffalo City Metropolitan Municipality', Administratio Publica 27(1), 78-93.

Sommerfeldt, E.J., 2012, 'The dynamics of activist power relationships: A structurationis exploration of the segmentation of activist publics', International Journal of Strategic Communication 6(4), 269-286. https://doi.org/10.1080/1553118X.2012.686256

Sørensen, E. \& Torfing, J., 2005, 'Network governance and post-liberal democracy' Administrative Theory and Praxis 27(2), 197-237. https://doi.org/10.1080/10841 Administrative Theor

Sprain, L., 2016, 'Paradoxes of public participation in climate change governance', The Good Society 25(1), 62-80. https://doi.org/10.5325/goodsociety.25.1.0062

Stein, S.M. \& Harper, T.L., 2003, 'Power, trust and planning', Journal of Planning Education and Research 23(2), 125-139. https://doi.org/10.1177/ 0739456X03258636

Tew, J., 2005, 'Power relations, social order and mental distress', in J. Tew (ed.), Social perspectives in mental health, pp. 71-89, Jessica Kingsley, London.

Van Holm, E.J., 2019, 'Unequal cities, unequal participation: The effect of income inequality on civic engagement', American Review of Public Administration 49(2), 135-144. https://doi.org/10.1177/0275074018791217
VaneKlasen, L. \& Miller, V., 2006, 'Dynamics of power, inclusion and exclusion', Nonprofit Online News Journal May, 38-56.

Vasstrøm, M. \& Normann, R., 2019, 'The role of local government in rural communities: Culture-based development strategies', Local Government Studies 45(6), 848868. https://doi.org/10.1080/03003930.2019.159020

Waldo, D., 1981, The enterprise of public administration: A summary view, Chandler \& Sharp, Novato, CA.

Walker, D., 2018, 'Leveraging communities' capabilities to increase accountability for health rights: The case of citizen voice and action', Journal of Human Development and Capabilities 19(2), 181-197. https://doi.org/10.1080/194528 29.2017.1411894

Wang, F., Jun, K-N. \& Wang, L., 2021, 'Bureaucratic contacts and their impact on citizen satisfaction with local government agencies: The influence of expectation', Public Policy and Administration 36(1), 41-68. https://doi.org/10.1177/095207671 9840065

Wargent, M., 2021, 'Localism, governmentality and failing technologies: The case of neighbourhood planning in England', Territory, Politics, Governance 9(4), 571 591. https://doi.org/10.1080/21622671.2020.1737209

Warren, S.E., Gerber, B.J. \& Robinson, S.E., 2013, Public Administration research methods: Tools for evaluation and evidence-based practice, Routledge, New York, NY.

Wilson, W., 1887, 'The study of administration', Political Science Quarterly 2(2), 197222. https://doi.org/10.2307/2139277

Wu, W. \& Jung, K., 2016, 'A missing link between citizen participation, satisfaction, and public performance: Evidences from the city and county of San Francisco', public performance: Evidences from the city and county of San Francisco',
International Journal of Public Sector Performance Management 2(4), 392-410. International Journal of Public Sector Perform
https://doi.org/10.1504/IJPSPM.2016.079720

Xu, H. \& Zhu, W., 2020, 'Evaluating the impact mechanism of citizen participation on citizen satisfaction in a smart city', EPB: Urban Analytics and City Science $0(0)$, 1-15. https://doi.org/10.1177/2399808320980746

Yount, K.M., Cheong, Y.F., Maxwell, L., Heckert, J., Martinez, E.M. \& Seymour, G., 2019 'Measurement properties of the project-level women's empowerment in Agriculture Index', World Development 124, 104639. https://doi.org/10.1016/j. worlddev.2019.104639

Zakhour, S., 2020, 'The democratic legitimacy of public participation in planning: Contrasting optimistic, critical, and agnostic understandings', Planning Theory 19(4), 349-370. https://doi.org/10.1177/1473095219897404

Zhu, D.H. \& Westphal, J.D., 2021, 'Structural power, corporate strategy, and performance', Strategic Management Journal 42, 624-651. https://doi. org/10.1002/smj.323 